(C) Telkom University

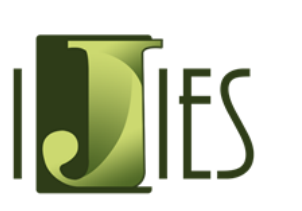
INTERNATIONAL JOURNAL OF INNOVATION IN
ENTERPRISE SYSTEM

Journal homepage: https://ijies.sie.telkomuniversity.ac.id/index.php/IJIES/index

Telkom

e-ISSN: 2580-3050

\title{
The Effect of Providing Government-Borne Import Duties Facility on the Growth and Competitiveness of Indonesia's Manufacturing Industry
}

\author{
Hendang Setyo Rukmi ${ }^{1 *}$, Lukmanulhakim Almamalik ${ }^{2}$ \\ ${ }^{1}$ Institut Teknologi Nasional \\ Jl. PH.H. Mustopha No. 23, Bandung, 40124, INDONESIA \\ ${ }^{2}$ Politeknik Piksi Ganesha \\ Jl. Gatot Subroto NO. 301, Bandung, 40274, INDONESIA \\ *hendang@itenas.ac.id
}

\section{ARTICLE INFO}

Article history:

Received 27 February 2020

Accepted 14 July 2020

Published 30 July 2020
Keywords:

Government-Borne Import

Duties Facility; production growth, competitiveness, employment, state revenue

\begin{abstract}
A B S T R A C T
This research has its aim to study the effect of providing Government-Borne Import Duty facility on the growth and competitiveness of Indonesia's manufacturing industry. The growth of the manufacturing industry is identified with the growth of production, employment, and contribution to state income through taxes. The background of this research is the existence of government's need to find the effect of the provision of exemption from import duties that have been running since 2008 on the ability of companies to produce goods in order to meet consumer needs, competitiveness, employment, and their contribution to state income. The survey was conducted on 110 companies that use this facility in Indonesia. The research applied the statistical method of sign and percentage test with the unit of analysis at the company and target sector, and groups of companies that receive GBID facility with different frequencies. The results show that the provision of the facility significantly increase the growth and competitiveness of Indonesia's manufacturing industry, especially in production growth, the competitiveness of production costs, sales growth, profits, and company productivity. This facility has different effects on companies under different target sectors. More companies under the guidance of Directorate General of MMTEI experinence innovation raising, time-to-market competitiveness, and machine modernization after being given this facility, while more companies under the guidance of Directorate General of CTMI experience production growth, competitiveness raising in production costs, quality, delivery time, sales growth, productivity, human capital, absorption of production labor, and tax payments. The reason related to this case is the existence of difference in production, product standardization, product cycle times, and technological intensity. The results also show that the difference in frequency of facilitation given only affect in rising the competitiveness of the company's products' price. Related to the nature of production, GBID facility is more suitable to be given to companies that have production plans rather than companies that only do the task based on project or job orders. It is because the companies that have production plan could do the job with more optimal results than those who don't.
\end{abstract}

\section{Introduction}

The American economic crisis in 2008 affected many countries in the world including Indonesia. The crisis had caused a decline in the growth of Indonesia's manufacturing industry from an average of above $4 \%$ to $1.5 \%$ (YoY) in line with the decline in product exports. Some manufacturing companies in Indonesia laid off employees and closed factories so unemployment increased and purchasing power decreased[1]. When Indonesia's manufacturing industry began to recover from the 2008 economic crisis, the performance of Indonesia's manufacturing industry was again affected by the economic crisis in the United States and Europe in 2013. The threat of non-oil and gas trade deficit on the Indonesian economy arised because imports continued to increase due to the rising of domestic consumption and 
the declining of export performance due to the weakening of global growth. The threat of non-oil and gas trade deficits that arised during the global economic crisis was due to the non-oil and gas manufacturing industry in Indonesia that still relied on imported raw materials[2].

From 2001 to 2013, the performance of imports of raw materials and supporting materials for industry tended to increase steadily, reaching $76 \%$ of the total imports of raw materials, capital goods, and consumer goods. The high import of raw materials and supporting materials affected the import costs that had to be paid by industries that imported raw materials[2]. These conditions weakened the competitiveness of Indonesia's manufacturing industry and made the growth of Indonesia's manufacturing industry decline so that it cut labor absorption, and even to the point of closure in some industries. The closure of industries that produce products or goods that are needed by the community cause scarcity of these products or goods.

To anticipate the impact of the crisis on the manufacturing industry related to the import of raw materials, the Government has issued several policies, including the provision of import facility for export, free trade agreements with other countries, such as the User-Specific Duty-Free Scheme, and fiscal incentive policy in the form of import duties borne by the Government. The purpose of issuing these policies is to reduce trade barriers in the form of import tariffs so that industries can obtain raw materials at lower import costs. This will certainly help industries that use imported raw materials to reduce their production costs so that they are expected to increase production output and productivity. The increasing of productivity as a result of the use of cheaper imported raw materials due to a reduction in tariffs is obtained through several factors included the learning process, the addition of variations in raw materials, as well as the quality effect of imported raw materials [2], [3].

One of the industrial policies related to the import of industrial raw materials is providing Government-Borne Import Duty facilities. GBID is given by the Government to companies that receive facilities if they can meet the following criteria[4] namely: 1) are able to meet the supply of goods and/or services for the public interest, consumed by the wider community and/or protecting consumers, 2) have competitiveness in the country, 3 ) have the potential to absorb labor, and 4) contribute to state income. Unlike the IFE and USDFS, GBID is a policy that has a characteristic as perfect substitution with the policy of the Free Trade Area and the IFE [2]. This means that if the company has utilized the FTA or IFE policy, then the company is not allowed to apply for imports using the GBID facility in the same year. Whereas GBID can be complementary or substitute with the Most Favoured Nation scheme. This means that the company can use the GBID and MFN facilities together or only use one of the two facilities in the same year.

Since it was rolled out in 2008 until 2018, the GBID facility has been provided to 241 Indonesian manufacturing companies, divided into 41 industrial sectors. The accumulated value that has been absorbed amounts to 2,083 trillion (IDR), realized import value of 1,869 billion (USD), and tariff posts used as many as 474 HS, originating from 51 countries. Every company that receives GBID will be verified by an independent surveyor related to raw material requirements and production quantities [5]. In addition the company must also report sales data, labor data, and tax data in the year of receiving GBID facility. Because the condition of the company after receiving GBID facility varies, the government, through the Ministry of Industry, wants to examine whether the policy of providing GBID facility has a positive effect on growth and competitiveness, referring to the criteria [4]. This positive effect occurs when the growth and competitiveness of the manufacturing industry in Indonesia after receiving GBID facility increase. Previous research shows that the reduction in import tariffs had a significant effect on production output and productivity of large and medium scale manufacturing industries in Indonesia [3]. However, the study was not related to GBID facility because the GBID facility only took effect in 2008. Research related to GBID shows that GBID facility had a statistically significant impact on the growth of Total Productivity Factor in 17 certain industries, but the resulting impact was low [2]. The reason for the low impact was due to the delay in issuing technical regulations on the GBID. Other facts show that the provision of GBID facility in the aviation industry, heavy equipment industry, and the vehicle industry was considered not optimal and its impact on industrial growth, competitiveness, competitiveness, and tax revenue for the country was still low [6].

The research has its aimed to examine the effect of providing the GBID facility on the growth and competitiveness of the Indonesian manufacturing industry. This study applied an analytical method in the form of statistical methods that can process ordinal data (percentage method and test marks). The analysis method was applied because of the data that can be taken in the form of data has an ordinal measurement scale. Besides, from companies that receive this facility each year, the number, type, and industrial sector can be different. There were several companies that only receive the facility for one or two years. It was not possible for this study to acquire the data in the form of numbers related to the companies' contiditon. The unavailbaility of data number made the the calculation of total productivity growth would not be impossible to be carried out. In this study, the condition of Indonesia's manufacturing industry was studied more broadly, not only in its productivity but also in its four capability criteria [4].

The GBID policy which has been running for 10 years needs to be evaluated so that it can give feedback data for the future development of the Indonesian manufacturing industry. This study has its aim to examine the effect of providing GBID facility to the growth and competitiveness of Indonesia's manufacturing industry. The research method applied in this study is statistical methods. Statistical method is considered to be applied in this study because it can process ordinal data (percentage methods and test marks) to proces the data which not all companies want to provide in the form of numbers. The data that can be retrieved in this study is only the data that shows the condition of the 
company after receiving BMDTP facilities (ordinal scale). Therefore, the calculation of total productivity growth will not be examined in this study. In this study, the condition of Indonesia's manufacturing industry is studied more broadly, not only based on its productivity but also included the four capability criteria in [4].

Companies that receive BMDTP facilities can be grouped into 3 categories, namely companies that are under the guidance of the Directorate General of Chemical, Textile and Multifarious Industries (CTMI), companies that are under the guidance of the Directorate General of Metal Industries, Machinery, Transportation Equipment, and Electronics (MMTEI), and companies that are under the guidance of the Directorate General of Agro Industry. Each category has different characteristics. These differences are reviewed from the nature of production, product standardization, product cycle times, and technological intensity. Besides based on these categories, companies receiving BMDTP facilities can be grouped according to the frequency of BMDTP received. It is predicted that the effects of BMDTP facilities will be different for industry groups from different target sectors and for different industry groups the frequency of BMDTP receipts.

\author{
Nomenclature \\ CTMI - Chemical, Textile, and Multifarious Industries \\ FTA - Free Trade Area \\ GIBD - Government-Borne Import Duty \\ IFE - Import Facility for Export \\ MFN - Most Favoured Nation \\ MMTEI - Metal, Machinery, Transportation Equipment, and Electronics Industries \\ USDFS - User Specific Duty-Free Scheme
}

\title{
2. Literatur Review
}

\subsection{Government-Borne Import Duty}

Government Borne Import Duty is an import duty that must be paid by the Government of the Republic of Indonesia for imports of goods and materials carried out by Indonesian manufacturing companies with a fixed budget specified in the state budget [4]. This policy was issued to reduce trade barriers in the form of import tariffs so that the recipient company could obtain raw materials at lower import costs. Companies receiving this facility must meet the following criteria [5]. First, the user company can produce goods and/or services to meet the public interest, be consumed by the wider community, and/or protect consumers. Second, user companies have certain industrial competitiveness in the country. Third, user companies have the potential to absorb labor. And fourth, user companies have the potential to contribute to increase state revenue.

Besides being given to imported goods and materials originating from inter-country imports, the GBID facility is also given to goods and materials imported from outside the customs' area or released from bonded warehouses to other places within the-custom areas. However, this GBID facility cannot be granted for: (1) goods and materials subject to $0 \%$ import duty, (2) goods and materials subject to $0 \%$ import duty based on international agreements or agreements, (3) goods and materials subject to Anti Dumping Import Duties/Temporary Anti Dumping Duties, Safeguard Measures Import Duty/Temporary Safeguard Measures Duties, Retribution Duty Duties or Retaliation Measures Import Duties, (4) goods and materials imported by companies in bonded stockpiles, and (5) goods and materials imported by companies that obtain import duty exemption/return facilities on imported goods and materials to be processed, assembled or installed on other goods for export.

\subsection{Company Competitiveness}

The term competitiveness refers to a measure of comparison between companies in an industry or its external environment. Competitiveness is a multidimensional concept that can be explained at the company, industry, and national levels. At the company level, competitiveness is the company's ability to survive and develop. Companies must be able to create and maintain a competitive advantage to always stay ahead and survive in a competition. In this case, the company's competitiveness is seen as a driver, as a result of the company, and as a competitive advantage [7].

Researches on competitiveness and its indicators, in the company level, industrial sector, and country of the company have been widely carried out by experts and the results have been widely published in various literature. To analyze competitiveness, experts have identified that competitiveness can be analyzed using past performance indicators or potential competitiveness indicators which are grouped into financial and non-financial performance [7]. At the company level, indicators that can be used to measure competitiveness are: (1) costs, in this case, included production costs, labor productivity, use of production capacity, and availability of reserves production [8], [9], [10], (2) quality, in this case, is the product display, product acceptance period, product durability, speed of customer complaint resolution, and product compliance with design specifications [8], [9], [11], (3) product delivery time, included production timeliness, production waiting time, and product delivery time [8], (4) flexibility, included the types of produced product and speed of adjusting to environmental interests [8], (5) delivery dependability, is a 
company's ability to provide the type and volume of products on time according to customer demand [9], (6) product innovation is a company's ability to introduce new products and features to the market. [9], [11], (7) time to market, is a company's ability to introduce new products faster than competitors [9], (8) market share is a company's ability to increase market share is as one of the logical consequences of increasing competitiveness [10], [12], (9) productivity, is a company's ability to increase productivity due to lower costs [10], [12], (10) profitability, is a company's ability to measure competitiveness to increase company profits (gross profit margin) [10], [12], [13], (11) price competitiveness [9], [10], (12) technology, includes R\&D expenditure, employment of qualified scientists and engineers, number of patents, royalty income and licensing [10],[11], (13) brand [11], (14) effective management of organizational [11], (15) human capital [11], and (16) growth is measured as the annual change of turnover value [13].

\section{Methodology}

The approach used in this research was descriptive-quantitative. It combined desk study analysis with on-site surveys to get a complete study. Desk analysis was applied based on literature studies and documentation studies using data and information that were easily obtained from various sources, such as GBID verification reports, the internet, and others. While the on-site survey was conducted to obtain facts and information directly from the field in the companies that received the GBID facility and was involved as research respondents. Broadly speaking, the stages of this study were included three stages.

The first stage was conducting a research design by preparing a measurement instrument (questionnaire) and determining the companies under study. The research measurement instrument was designed to assess changes in the conditions of Indonesian manufacturing companies after receiving the GBID facility. Changes in company conditions were measured from the following four aspects [3]. Every aspect of the change in the measured condition was determined by the measurement indicator. The aspect of the ability to produce goods to meet consumer needs was measured using indicators of production volume and raw material volume because the utilization of average production capacity will increase output in line with increased market demand [14]. Aspects of competitiveness, the measurement indicators determined refer to [8], [9], [10], [11], [12], and [13]. For the aspect of employment, indicators for the number of production and non-production workers were used. For the aspect of company contribution to state income, indicators for payment of corporate income tax and worker income tax paid by companies were used by the company. Taxes are the main source of state revenue to finance government spending [15]. The largest percentage of tax revenue realization in Indonesia comes from income tax. For the Indonesian government, the manufacturing industry is the country's foundation in tax revenue because its growth is the largest compared to other industrial sectors [16].

In this research, the object of this research was the company that received the GBID facility. The number of companies that have received it during the 2008-2018 period was 241 companies. Not all companies would be the object of this research. The sample companies must fulfil the criteria in order to be taken as objects in this study. To meet the citeria, they had to receive GBID facility at least one year and or that company received it last year (2018). There were 131 companies that met these criteria because they had easy access to data collection and in the group of manufacturing companies that received GBID facility. These 113 companies that spread throughout Indonesia then could be surveyed for data collection. Companies that receive this facility can be grouped into 3 categories, namely companies that are under the guidance of the Directorate General of Chemical, Textile and Multifarious Industries, companies that are under the guidance of the Directorate General of Metal, Machinery, Transportation Equipment, and Electronics Industries, and companies that are under the guidance of the Directorate General of Agro-Industries.

The object of this study is the company receiving GBID facility. The number of companies that have received GBID facility during the 2008-2018 period is 241 companies. The companies studied were companies that received GBID facility in 2018 and were easily accessed for data collection. In total there were 113 companies that meet these criteria. The location was spread all over Indonesia. Companies that receive GBID facility can be grouped into 3 categories, namely companies that are under the guidance of the Directorate General of Chemical, Textile and Multifarious Industries (CTMI), companies that are under the guidance of the Directorate General of Metal Industries, Machinery, Transportation Equipment, and Electronics (MMTEI), and companies that are under the guidance of the Directorate General of Agro Industry.

Question items were arranged for each indicator and measurement scale. The questionnaire that was designed closed. Because it was not possible to ask for company condition data in the form of numbers, the choice of answers given for each question about the condition of the company was down (negative), fixed (zero), and up (positive). Indicators, sub-indicators, and research questions can be seen in Appendix A.

The second stage was data collection. The research data was collected by surveying the company. Before the survey was conducted, the researcher sent questionnaires to 113 companies via e-mail to enable the company to study the questionnaire sent. Furthermore, the researcher was assisted by the Surveyor to collect data together with the manager or person appointed by the company to fill out the questionnaire independently.

The last step was processing and analyzing as well as drawing conclusions and suggestions. After being collected, the questionnaire data were processed using percentages and test marks. The percentage was used to determine the composition of the company for each group of different conditions after getting the GBID assistance program. The Sign Test was used to test the hypothesis of whether there are differences in the conditions of the companies studied before 
and after receiving the GBID facility. It was used because the data was in ordinal form and was expressed in the form of positive or negative changes, and the samples taken correlated each other (before and after getting GBID facility).

\section{Data Analysis and Result}

There were 113 companies where the questionnaire were sent, but only 110 companies filled out and returned the questionnaire. Companies that filled out and returned the questionnaire were then surveyed. Of the 110 companies studied, 62 companies under the guidance of the Directorate General of CTMI, 47 companies under the guidance of the Directorate General of MMTEI, and one company under the guidance of the Directorate General of Agro-Industries. Based on the number of frequency of facility received by the company, the companies studied were divided into four categories, namely those who received once amounted to 21 companies, those who received twice amounted to 21 companies, those who received three times the number of 10 companies, and those who received more than three times the number 58 companies.

Table 1 shows the table of results of the processing of Sign Test data for all respondents. The results of data processing companies under the guidance of the Agro directorate are not displayed because they cannot yet represent the results of the guidance of this sector in general considering the sample is only 1 company and the company only received the BMDTP facility in 2018. The data processing results show two things, namely 1) no there is a change in the company's condition after the company receives the GBID facility (Ho is accepted or $\mathrm{H}_{1}$ is rejected), and 2) there is a change in the company's condition after the company receives the GBID facility (Ho is rejected or $\mathrm{H}_{1}$ is accepted). Each indicator/sub-indicator has the null hypothesis (Ho) tested. Ho is accepted if P-value $>\alpha$. Conversely, Ho is rejected if the P-value $\leq \alpha$. In this study the value of $\alpha=0.05$ was used. From Table 1 it can be seen that for the category of all company, the P-value of all indicators examined $\leq \alpha$. This means that there are significant differences in conditions between before and after the manufacturing industry receives GBID facility for all indicators studied that refer to the criteria [3]. The same conditions occur for groups of companies under the guidance of the Directorate General of IKTA, while for companies under the guidance of the Directorate General of ILMATE, there are indicators of company conditions that do not change significantly, namely pph 25 taxes paid by companies. Sign Test Results for manufacturing industry groups that have a different frequency of GBID reception show that the manufacturing industry group receiving GBID facility more than three times has the best conditions compared to other groups.

Table 2 shows the table of data processing results with the percentage method for all respondents who experienced better conditions after receiving the GBID facility. From Table 2, it can be seen that the impact of GBID facility that mostly occurred in all companies (more than 60\% of companies), both CTMI target groups and MMTEI target groups were increasing raw material volume, decreasing production costs, increasing sales growth, and increasing company profit. The percentage of companies that experienced an increase in competitiveness in production costs was around $57.45 \%-59.68 \%$ of companies and the percentage of companies that experienced a decline in selling prices was around $38.3 \%-40.32 \%$ of companies. From table 2 it can also be seen that the percentage of companies experiencing: (1) an increase in the capital after receiving GBID only ranged from 20\%-30\% of the company, (2) an increase in product innovation there were around $38 \%-50 \%$ of the company, (3) an increase in competitiveness quality there were around $25 \%-40 \%$, (4) improvement in the competitiveness of delivery time there were around $23 \%-40 \%$ of companies, (5) experiencing modernization of machine tools there were about 19\%-20\% of companies, (6) increasing competence of production workforce there were about 23\%-33\% of companies, and (7) the increase in contribution to state revenue, especially from corporate tax was only around $20 \%-50 \%$.

\section{Discussion}

This research has its aim to study the effect of providing Government Borne Import Duty facility on the growth and competitiveness of the Indonesian manufacturing industry at the company level during 2008-2018. Test results on all company data indicate that GBID facility has a positive effect on the growth and competitiveness of Indonesia's manufacturing industry. The conditions that occurred after the industries received GBID facility show the increasing of production growth, employment, corporate income tax payments, production cost competitiveness, selling price competitiveness, quality competitiveness, delivery time competitiveness, innovation, time to market, market share, company productivity, profit, machine modernization, and human capital. However, there were differences in the results of the test that were carried out on the manufacturing industry under the guidance of MMTEI and the manufacturing industry which had a different frequency of GBID reception. Manufacturing income tax payments of the manufacturing industry under the guidance of MMTEI before and after being given the GBID facility do not have a siginificant difference. Even though the test results show that there was a significant increase in company profits after the manufacturing industry under the guidance of MMTEI received the facility. In addition to Government Regulation No. 23/2018 regarding tax incentives, in Indonesia, a self-assessment system is applied so that taxpayers are given full discretion to calculate, pay, and report their tax obligations themselves. To reduce the amount of tax that must be paid, companies can take tax evasion or tax evasion actions. Tax avoidance is a legal and acceptable activity because taxpayers take advantage of opportunities that exist in taxation laws so that the tax paid becomes lower [16] 
The test results for manufacturing industry groups that have different GBID reception frequencies show that the manufacturing industry group receiving the facility more than three times has the best conditions compared to other groups. In the manufacturing industry group receiving GBID facility more than three times, only the non-production employment rate and the number of corporate tax deposits do not have a siginificant difference between before and after receiving GBID facility. The interesting thing is the effect of giving GBID facility to the GBID recipient manufacturing industry group three times is not as good as the effect of providing GBID facility to the GBID recipient manufacturing industry group once and twice. Indicators that have changed in a positive direction in the manufacturing industry group of GBID recipients are three times the smallest number. Indicators that show their increase are production growth, selling prices, innovation, market share, and corporate profits. Since the number of samples of the companies in the manufacturing industry group that receiving GBID three times are few, the data does not reflect the actual condition. Another factor is that the industrial group receiving GBID facility is mostly job orders so that the utilization of GBID facility is s less than optimal. Beyond the special conditions that have occurred in the GBID recipient industry group three times, this study shows that the intensity of the GBID facility has a positive effect on the growth and competitiveness of Indonesia's manufacturing industry.

The results of data processing using the percentage show that the most positive effects felt by companies receiving the GBID facility surveyed are the decrease in production costs and the increase in sales growth,-company profits, and volume of raw materials. Not all respondents that experienced a decrease in production costs also experienced an increase in the competitiveness of production costs and a decrease in the selling price of products. The amount of GBID facility received is considered by some companies to be insufficient to reduce production costs to the same level as its competitors, especially competitors from abroad. Other factors that influence the weak competitiveness of production costs are inefficient production and relatively low quality of human capital, which had an impact on company productivity. The data in Table 2, shows that companies that received a GBID facility that experienced an increase in human capital only ranged from $20 \%-30 \%$ of companies. Companies receiving GBID facility that has improved quality in human capital are lower than companies receiving GBID facility that have decreased production costs. Research [17] shows that a quality workforce results in the increase of organizational productivity.

Despite the decline in production costs, not all companies try to reduce the selling price to increase their competitiveness. Some companies strive to create quality and delivery time competitiveness through product innovation, machine modernization, and human capital development. Table 2 shows that there are around $19 \%-20 \%$ of companies that have experienced machinery/equipment modernization and there are around $23 \%-33 \%$ of companies that have experienced an increase in the competence of the production workforce. Human capital development needs to be done because besides being closely related, human resource development can contribute to innovation in many areas [18] [19]. With a fixed selling price but better quality and service (delivery time), the company's market share and profits have increased. However, not all respondents whose sales, market share, and profits that increased stated that their income corporate tax payments also increased. The contributing factors are the Government Regulation No. 23/2018 related to tax incentives and the implementation of a self-assessment system so that taxpayers can find ways to reduce taxes both legally and non-legally.

The provision of the GBID facility has different effects on companies under different target sectors. More companies under the guidance of MMTEI have experienced the increase in innovation, time-to-market competitiveness, and machine modernization after being given this facility, while more companies under the guidance of CTMI have experienced in production growth, increase in competitiveness in production costs, quality, delivery time, sales growth, productivity, human capital, absorption of production labor, and tax payments.

The companies under the guidance of MMTEI which were studied, particularly the metal and manufacturing industries, are partly job production in nature so that they can only propose this facility based on existing orders. If the company's orders are relatively the same from year to year, it is assumed that the production volume and the relative volume of raw material requirements will remain the same. Therefore the company does not need to increase the number of workers in the production department because the available workforce is still sufficient. GBID facility will be given after the Decree of the Minister of Finance related to GBID is determined. The amount of the budget ceiling given by the government is by company submissions submitted through the Ministry of Industry before the Minister of Finance Decree related to GBID is established. If an order comes after the Decree of the Minister of Finance regarding GBID is determined, the company could not apply for the facility so that the import of goods or raw materials to produce the product is carried out without obtaining the facility. Thus there is no reduction in production costs and the selling price is unlikely to be lowered so that market share and sales growth remain. Therefore, the facility is more suitable for companies that have production planning rather than companies that are project or job order.

The percentage of companies under the guidance of MMTEI that experiences the increase in modernization of machinery/equipment is more than companies under the guidance of CTMI. For some companies under the guidance of MMTEI which are job orders, the GBID facility allows them to get additional funds from the reduction of raw material import tariffs that can be utilized for the development of production process facilities towards the Flexible Manufacturing System. Flexible Manufacturing System is a must to accommodate unstable demands, varying product mixes, effective launching of new products in the market because flexibility makes the production system more productive and helps to reduce manufacturing lead time [20]. 
Table 1- $P$-value Calculation Result

\begin{tabular}{|c|c|c|c|c|c|c|c|c|}
\hline \multirow[b]{2}{*}{$\begin{array}{l}\text { Company's Condition } \\
\text { Indicators }\end{array}$} & \multirow[b]{2}{*}{$\begin{array}{l}\text { (Ho) Null Hipotesis } \\
\text { tested }\end{array}$} & \multicolumn{7}{|c|}{$P$-value } \\
\hline & & $\begin{array}{c}\text { All } \\
\text { Company }\end{array}$ & $\begin{array}{c}\text { CTMI } \\
\text { guidance }\end{array}$ & $\begin{array}{l}\text { MMTEI } \\
\text { guidance }\end{array}$ & $\begin{array}{c}\text { 1x } \\
\text { Receiver } \\
\text { GBID } \\
\end{array}$ & $\begin{array}{c}2 x \\
\text { Receiver } \\
\text { GBID } \\
\end{array}$ & $\begin{array}{c}\text { 3x } \\
\text { Receiver } \\
\text { GBID } \\
\end{array}$ & $\begin{array}{c}\text { 3x }> \\
\text { Receiver } \\
\text { GBID } \\
\end{array}$ \\
\hline \multirow{2}{*}{$\begin{array}{l}\text { The ability to produce } \\
\text { goods to meet consumer } \\
\text { needs }\end{array}$} & $\begin{array}{l}\text { There was no increase in } \\
\text { production volume after } \\
\text { the company received } \\
\text { GBID. }\end{array}$ & 0.0000 & 0.0000 & 0.0000 & 0.0005 & 0.0001 & 0.0156 & 0.0000 \\
\hline & $\begin{array}{l}\text { There was no increase in } \\
\text { raw material volume after } \\
\text { the company received } \\
\text { GBID. }\end{array}$ & 0.0000 & 0.0000 & 0.0000 & 0.0032 & 0.0001 & 0.0039 & 0.0000 \\
\hline \multirow[b]{2}{*}{ Cost competitiveness } & $\begin{array}{l}\text { There was no reduction in } \\
\text { production costs after the } \\
\text { company received GBID. }\end{array}$ & 0.0000 & 0.0000 & 0.0000 & 0.0001 & 0.0000 & 0.0020 & 0.0000 \\
\hline & $\begin{array}{l}\text { There was no increase in } \\
\text { the competitiveness of } \\
\text { production costs after the } \\
\text { company received GBID. }\end{array}$ & 0.0000 & 0.0000 & 0.0043 & 0.0461 & 0.0481 & $0.0898 *$ & 0.0002 \\
\hline \multirow{2}{*}{$\begin{array}{l}\text { Price } \\
\text { competitiveness }\end{array}$} & $\begin{array}{l}\text { There was no decrease in } \\
\text { product selling prices after } \\
\text { the company received } \\
\text { GBID. }\end{array}$ & 0.0000 & 0.0000 & 0.0053 & 0.0352 & $0.1445^{*}$ & 0.0313 & 0.0000 \\
\hline & $\begin{array}{l}\text { There was no increase in } \\
\text { selling price } \\
\text { competitiveness after the } \\
\text { company received GBID. }\end{array}$ & 0.0000 & 0.0000 & 0.0000 & 0.0112 & 0.0065 & 0.0625 & 0.0000 \\
\hline \multirow{2}{*}{ Quality competitiveness } & $\begin{array}{l}\text { There was no decrease in } \\
\text { the number of product } \\
\text { defects after the company } \\
\text { received GBID. }\end{array}$ & 0.0000 & 0.0017 & 0.0078 & $0.5000 *$ & 0.0039 & $0.5000^{*}$ & 0.0039 \\
\hline & $\begin{array}{l}\text { There was no increase in } \\
\text { quality competitiveness } \\
\text { after the company received } \\
\text { GBID. }\end{array}$ & 0.0000 & 0.0016 & 0.0002 & $0.0898 *$ & 0.0078 & $0.0625 *$ & 0.0022 \\
\hline \multirow{3}{*}{ Delivery time } & $\begin{array}{l}\text { There was no increase in } \\
\text { delivery time accuracy } \\
\text { after the company received } \\
\text { GBID. }\end{array}$ & 0.0000 & 0.0001 & 0.0352 & $0.5000^{*}$ & 0.0039 & $0.2500 *$ & 0.0059 \\
\hline & $\begin{array}{l}\text { There was no increase in } \\
\text { the speed of delivery time } \\
\text { after the company received } \\
\text { GBID. }\end{array}$ & 0.0000 & 0.0003 & 0.0039 & $0.5000 *$ & 0.0039 & $0.1250 *$ & 0.0032 \\
\hline & $\begin{array}{l}\text { There was no increase in } \\
\text { delivery time } \\
\text { competitiveness after the } \\
\text { company received GBID. }\end{array}$ & 0.0000 & 0.0000 & 0.0005 & $0.2500 *$ & 0.0039 & $0.0625 *$ & 0.0001 \\
\hline Innovation & $\begin{array}{l}\text { There was no increase in } \\
\text { the number of product } \\
\text { innovations after the } \\
\text { company received GBID. }\end{array}$ & 0.0000 & 0.0000 & 0.0000 & 0.0039 & 0.0039 & 0.0313 & 0.0000 \\
\hline Time to market & $\begin{array}{l}\text { There was no increase in } \\
\text { product launching speed } \\
\text { after the company received } \\
\text { GBID. }\end{array}$ & 0.0000 & 0.0000 & 0.0000 & 0.0156 & 0.0039 & $0.0625 *$ & 0.0000 \\
\hline \multirow{2}{*}{ Market share } & $\begin{array}{l}\text { There was no increase in } \\
\text { market share in the local } \\
\text { market after the company } \\
\text { received GBID. }\end{array}$ & 0.0000 & 0.0000 & 0.0000 & 0.0001 & 0.0005 & 0.0313 & 0.0000 \\
\hline & $\begin{array}{l}\text { There was no increase in } \\
\text { market share in the export } \\
\text { markets after the company } \\
\text { received GBID. }\end{array}$ & 0.0000 & 0.0000 & 0.0000 & 0.0010 & 0.0107 & 0.0313 & 0.0000 \\
\hline
\end{tabular}




\begin{tabular}{|c|c|c|c|c|c|c|c|c|}
\hline \multirow{3}{*}{$\begin{array}{l}\text { Company's Condition } \\
\text { Indicators }\end{array}$} & \multirow[b]{2}{*}{$\begin{array}{l}\text { (Ho) Null Hipotesis } \\
\text { tested }\end{array}$} & \multicolumn{7}{|c|}{$P$-value } \\
\hline & & $\begin{array}{c}\text { All } \\
\text { Company }\end{array}$ & $\begin{array}{c}\text { CTMI } \\
\text { guidance }\end{array}$ & $\begin{array}{l}\text { MMTEI } \\
\text { guidance }\end{array}$ & $\begin{array}{c}1 \mathrm{x} \\
\text { Receiver } \\
\text { GBID }\end{array}$ & $\begin{array}{c}\mathbf{2 x} \\
\text { Receiver } \\
\text { GBID }\end{array}$ & $\begin{array}{c}\mathbf{3 x} \\
\text { Receiver } \\
\text { GBID }\end{array}$ & $\begin{array}{c}\mathbf{3 x}> \\
\text { Receiver } \\
\text { GBID }\end{array}$ \\
\hline & $\begin{array}{l}\text { There was no increase in } \\
\text { sales growth after the } \\
\text { company received GBID. }\end{array}$ & 0.0000 & 0.0000 & 0.0000 & 0.0001 & 0.0000 & 0.0156 & 0.0000 \\
\hline Company Productivity & $\begin{array}{l}\text { There was no increase in } \\
\text { company productivity } \\
\text { after the company received } \\
\text { GBID. }\end{array}$ & 0.0000 & 0.0000 & 0.0000 & 0.0000 & 0.0000 & $0.1875^{*}$ & 0.0000 \\
\hline Profitability & $\begin{array}{l}\text { There was no increase in } \\
\text { company profitability after } \\
\text { the company received } \\
\text { GBID. }\end{array}$ & 0.0000 & 0.0000 & 0.0000 & 0.0000 & 0.0000 & 0.0078 & 0.0000 \\
\hline \multirow[b]{2}{*}{$\begin{array}{l}\text { Modernization of } \\
\text { machines }\end{array}$} & $\begin{array}{l}\text { There was no increase in } \\
\text { investment in machinery } \\
\text { lequipment after the } \\
\text { company received GBID. }\end{array}$ & 0.0000 & 0.0000 & 0.0000 & 0.0078 & 0.0001 & $0.5000 *$ & 0.0000 \\
\hline & $\begin{array}{l}\text { There was no } \\
\text { improvement in } \\
\text { technology quality after } \\
\text { the company received } \\
\text { GBID. }\end{array}$ & 0.0000 & 0.0001 & 0.0001 & 0.0313 & $0.0625^{*}$ & $0.1250 *$ & 0.0000 \\
\hline \multirow{2}{*}{ Human capital } & $\begin{array}{l}\text { There was no increase in } \\
\text { labor competency after the } \\
\text { company received GBID. }\end{array}$ & 0.0000 & 0.0000 & 0.0005 & 0.0313 & 0.0078 & $0.1250 *$ & 0.0002 \\
\hline & $\begin{array}{l}\text { There was no increase in } \\
\text { labor productivity after the } \\
\text { company received GBID. }\end{array}$ & 0.0000 & 0.0000 & 0.0001 & 0.0156 & 0.0010 & $0.1250 *$ & 0.0000 \\
\hline \multirow[b]{2}{*}{ Labors absorption } & $\begin{array}{l}\text { There was no increase in } \\
\text { the number of production } \\
\text { laborers after the company } \\
\text { received GBID. }\end{array}$ & 0.0000 & 0.0000 & 0.0007 & 0.0156 & 0.0010 & $0.2500 *$ & 0.0000 \\
\hline & $\begin{array}{l}\text { There was no increase in } \\
\text { the number of non- } \\
\text { production laborers after } \\
\text { the company received } \\
\text { GBID. }\end{array}$ & 0.0005 & 0.0107 & 0.0287 & $0.1250 *$ & 0.0078 & $0.5000 *$ & $0.0898 *$ \\
\hline \multirow[b]{2}{*}{$\begin{array}{l}\text { Contribute to increasing } \\
\text { state revenues }\end{array}$} & $\begin{array}{l}\text { There was no increase in } \\
\text { company tax paid after the } \\
\text { company received GBID. }\end{array}$ & 0.0000 & 0.0367 & $0.2431 *$ & $0.2120^{*}$ & $0.1796^{*}$ & $0.6875^{*}$ & $0.0825 *$ \\
\hline & $\begin{array}{l}\text { There was no increase in } \\
\text { the labor tax that the } \\
\text { company paid after the } \\
\text { company received GBID. }\end{array}$ & 0.0000 & 0.0000 & 0.0105 & 0.0195 & $0.0717 *$ & $0.1250 *$ & 0.0002 \\
\hline
\end{tabular}

Note : * Ho accepted as $P$-value $\geq 0.05$

Tabel 2- Company Data Experience Better Conditions after Receiving the GBID Facility (\%)

\begin{tabular}{|c|c|c|c|c|c|c|c|c|}
\hline \multirow[b]{2}{*}{$\begin{array}{c}\text { Company's } \\
\text { Condition Indicators }\end{array}$} & \multirow[b]{2}{*}{$\begin{array}{c}\text { Conditions experienced } \\
\text { by the company }\end{array}$} & \multicolumn{7}{|c|}{ Percentage of the company in better condition $(\%)$} \\
\hline & & $\begin{array}{c}\text { All } \\
\text { Company }\end{array}$ & $\begin{array}{c}\text { CTMI } \\
\text { guidance }\end{array}$ & $\begin{array}{l}\text { MMTEI } \\
\text { guidance }\end{array}$ & $\begin{array}{c}\text { 1x } \\
\text { Receiver } \\
\text { GBID } \\
\end{array}$ & $\begin{array}{c}2 x \\
\text { Receiver } \\
\text { GBID } \\
\end{array}$ & $\begin{array}{c}\mathbf{3 x} \\
\text { Receiver } \\
\text { GBID } \\
\end{array}$ & $\begin{array}{c}\mathbf{3 x}> \\
\text { Receiver } \\
\text { GBID } \\
\end{array}$ \\
\hline \multirow{2}{*}{$\begin{array}{l}\text { The ability to produce } \\
\text { goods to meet } \\
\text { consumer needs }\end{array}$} & $\begin{array}{l}\text { Increased production } \\
\text { volume }\end{array}$ & 62.73 & 69.35 & 53.19 & 52.38 & 76.19 & 60.00 & 62.07 \\
\hline & $\begin{array}{l}\text { The increased volume of } \\
\text { raw materials }\end{array}$ & 69.09 & 74.19 & 61.70 & 52.38 & 76.19 & 80.00 & 70.69 \\
\hline \multirow[b]{2}{*}{ Cost competitiveness } & $\begin{array}{l}\text { Decreasing production } \\
\text { costs }\end{array}$ & 88.18 & 90.32 & 85.11 & 80.95 & 90.48 & 90.00 & 89.66 \\
\hline & $\begin{array}{l}\text { Increasing the } \\
\text { competitiveness of } \\
\text { production costs }\end{array}$ & 59.09 & 59.68 & 57.45 & 47.62 & 61.90 & 70.00 & 60.34 \\
\hline Price & The decline in product & 40.00 & 40.32 & 38.30 & 33.33 & 28.57 & 30.00 & 48.28 \\
\hline
\end{tabular}




\begin{tabular}{|c|c|c|c|c|c|c|c|c|}
\hline \multirow[b]{2}{*}{$\begin{array}{c}\text { Company's } \\
\text { Condition Indicators }\end{array}$} & \multirow[b]{2}{*}{$\begin{array}{c}\text { Conditions experienced } \\
\text { by the company }\end{array}$} & \multicolumn{7}{|c|}{ Percentage of the company in better condition $(\%)$} \\
\hline & & $\begin{array}{c}\text { All } \\
\text { Company }\end{array}$ & $\begin{array}{c}\text { CTMI } \\
\text { guidance }\end{array}$ & $\begin{array}{l}\text { MMTEI } \\
\text { guidance }\end{array}$ & $\begin{array}{c}\mathbf{1 x} \\
\text { Receiver } \\
\text { GBID } \\
\end{array}$ & $\begin{array}{c}2 x \\
\text { Receiver } \\
\text { GBID } \\
\end{array}$ & $\begin{array}{c}\mathbf{3 x} \\
\text { Receiver } \\
\text { GBID } \\
\end{array}$ & $\begin{array}{c}3 x> \\
\text { Receiver } \\
\text { GBID } \\
\end{array}$ \\
\hline \multirow[t]{2}{*}{ competitiveness } & selling prices & & & & & & & \\
\hline & $\begin{array}{l}\text { Increased selling price } \\
\text { competitiveness }\end{array}$ & 59.09 & 56.45 & 61.70 & 52.38 & 57.14 & 40.00 & 65.52 \\
\hline \multirow{2}{*}{$\begin{array}{l}\text { Quality } \\
\text { competitiveness }\end{array}$} & $\begin{array}{l}\text { Decreased number of } \\
\text { product defects }\end{array}$ & 17.27 & 19.35 & 14.89 & 9.52 & 38.10 & 10.00 & 13.79 \\
\hline & $\begin{array}{l}\text { Increasing quality } \\
\text { competitiveness }\end{array}$ & 30.91 & 33.87 & 25.53 & 33.33 & 33.33 & 40.00 & 27.59 \\
\hline \multirow{3}{*}{ Delivery time } & $\begin{array}{l}\text { Improved delivery time } \\
\text { accuracy }\end{array}$ & 19.09 & 22.58 & 14.89 & 4.76 & 38.10 & 20.00 & 17.24 \\
\hline & $\begin{array}{l}\text { Increased delivery time } \\
\text { speed }\end{array}$ & 20.91 & 24.19 & 17.02 & 4.76 & 38.10 & 30.00 & 18.97 \\
\hline & $\begin{array}{l}\text { Increased delivery time } \\
\text { competitiveness }\end{array}$ & 25.45 & 27.42 & 23.40 & 9.52 & 38.10 & 40.00 & 24.14 \\
\hline Innovation & $\begin{array}{l}\text { Increase in the number of } \\
\text { product innovations }\end{array}$ & 40.00 & 38.71 & 40.43 & 38.10 & 38.10 & 50.00 & 39.66 \\
\hline Time to market & $\begin{array}{l}\text { Increased product } \\
\text { launching speed }\end{array}$ & 35.45 & 33.87 & 36.17 & 28.57 & 38.10 & 40.00 & 36.21 \\
\hline \multirow{3}{*}{ Market share } & $\begin{array}{l}\text { Increased market share in } \\
\text { the local market }\end{array}$ & 52.73 & 56.45 & 46.81 & 66.67 & 52.38 & 50.00 & 48.28 \\
\hline & $\begin{array}{l}\text { Increased market share in } \\
\text { foreign markets }\end{array}$ & 38.18 & 33.87 & 42.55 & 47.62 & 42.86 & 50.00 & 31.03 \\
\hline & Increased sales growth & 72.73 & 75.81 & 68.09 & 61.90 & 85.71 & 60.00 & 74.14 \\
\hline Company productivity & $\begin{array}{l}\text { Increased company } \\
\text { productivity }\end{array}$ & 60.91 & 64.52 & 55.32 & 71.43 & 76.19 & 40.00 & 55.17 \\
\hline Profitability & $\begin{array}{l}\text { Increased company } \\
\text { profitability }\end{array}$ & 77.27 & 75.81 & 78.72 & 85.71 & 80.95 & 70.00 & 74.14 \\
\hline \multirow{2}{*}{$\begin{array}{l}\text { Modernization of } \\
\text { machines }\end{array}$} & $\begin{array}{l}\text { Increased investment in } \\
\text { machinery/ equipment }\end{array}$ & 41.82 & 37.10 & 46.81 & 33.33 & 66.67 & 10.00 & 41.38 \\
\hline & $\begin{array}{l}\text { Improved technology } \\
\text { quality }\end{array}$ & 25.45 & 22.58 & 29.79 & 23.81 & 19.05 & 30.00 & 27.59 \\
\hline \multirow{2}{*}{ Human capital } & $\begin{array}{l}\text { Increased workforce } \\
\text { competence }\end{array}$ & 24.55 & 24.19 & 23.40 & 23.81 & 33.33 & 30.00 & 20.69 \\
\hline & $\begin{array}{l}\text { Increased labor } \\
\text { productivity }\end{array}$ & 30.91 & 32.26 & 27.66 & 28.57 & 47.62 & 30.00 & 25.86 \\
\hline \multirow{2}{*}{ Labors absorption } & $\begin{array}{l}\text { Increasing the number of } \\
\text { production workers }\end{array}$ & 37.27 & 38.71 & 34.04 & 28.57 & 47.62 & 20.00 & 39.66 \\
\hline & $\begin{array}{l}\text { Increasing the number of } \\
\text { non-production workers }\end{array}$ & 19.09 & 14.52 & 23.40 & 14.29 & 33.33 & 10.00 & 17.24 \\
\hline \multirow{2}{*}{$\begin{array}{l}\text { Contribute to } \\
\text { increasing state } \\
\text { revenues }\end{array}$} & $\begin{array}{l}\text { Increase in company tax } \\
\text { paid }\end{array}$ & 44.55 & 46.77 & 40.43 & 42.86 & 57.14 & 20.00 & 44.83 \\
\hline & Increase in labor tax paid & 49.09 & 53.23 & 42.55 & 38.10 & 57.14 & 30.00 & 53.45 \\
\hline
\end{tabular}

Companies under the guidance of CTMI which were studied are industries that have medium-high technological intensity where the products they produce are customized. Companies that produce customized products are better able to meet demands on time because of shorter set-up times [21]. Besides, companies with high technology intensity must conduct internal technology learning through learning by doing activities to improve their technological capabilities. Learning internal technology generally involves top-level management and employees, especially knowledge workers because learning internal technology innovation will be kept confidential. This is one of the reasons why the increase in human capital is mostly done by companies receiving facilities under the guidance of CTMI.

Companies under the guidance of CTMI are mostly companies in the chemical and pharmaceutical sectors which produce customized products. According to [21] companies that produce customized products will be asked to meet demand promptly. It could can be one of the reasons why the company under the guidance of CTMI can increase the competitiveness of delivery times more than the percentage of companies under the guidance of MMTEI. Companies under the guidance of MMTEI, which experienced an increase in the number of product innovations and the speed of product launching after receiving the GBID facility are more than the percentage of companies under the CTMI target sector. Companies under the guidance of MMTEI, especially in the electronics industry component sector, face dramatic changes. The increase in speed, the reduce in feature size and supply voltage, and changes in interconnection and packaging technology to events that occur almost every month making the life cycle of electronic components 
shorter [22]. In an industry that changes rapidly, companies must constantly introduce new products to survive and adapt their strategies to change[23]. The new product launching must be faster than competitors. These conditions encourage the need for high levels of product innovation and new product launching that are faster than competitors. The GBID facility allows companies to allocate a portion of the budget that was originally intended for the purchase of goods or raw materials to the field of research and development and/or investment in more modern machinery to increase and accelerate product innovation. The field of research and development is in charge of product development, a stage that is needed for an organization to innovate products [24].

Companies under the guidance of CTMI experience an increase in human capital greater than the percentage of companies under the guidance of MMTEI. Companies under the guidance of CTMI such as the pharmaceutical, plastic, and resin industry are industries that have medium-high technological intensity[25].[21] show that companies with high technology intensity tend to do internal technology learning through learning by doing activities to improve their technological capabilities. Learning internal technology generally involves top-level management and employees, especially knowledge workers because learning internal technology innovation will be kept confidential.

Sign test results for groups of companies receiving GBID facility with different frequencies, as listed in Table 2, show that the group of companies receiving facilities 3 times experienced the most significant changes in the indicator of company conditions, followed by the group of companies receiving facilities twice, the group of companies receiving facilities once, and a group of companies receiving GBID facility more than 3 times. Group of companies receiving GBID facility more than tree times the number of samples at least and many companies are job production. Table 2 shows that the reduction in production costs is the condition most experienced by companies (above $80 \%)$ in each group of recipients of GBID facility once, twice, three times, and more than three times. Other conditions that also experienced by companies from GBID facility recipients with different frequencies are increase in sales growth (above $60 \%$ ), increase in company profitability (above 70\%), and increase in production volumes and raw materials (above $50 \%$ ). The group of companies that gets GBID facility more than three times has the biggest percentage for an indicator of increasing price competitiveness. This means that increasing price competitiveness is the condition most experienced by companies receiving the GBID facility more than three times. Thus, the frequency of giving GBID facility that more often will increase the ability of the company's price competitiveness. For other company condition indicators other than increasing price competitive indicators, the intensity of the GBID facility is not visible. Table 2 data shows that the percentage of companies in better condition for other indicators, in addition to an increase in price-competitive indicators, does not increase in line with the increase in the frequency of GBID receipts. This condition occurs because the composition of companies in each group of GBID recipient companies with different frequencies is quite diverse, some from the CTMI target group and some from the MMTEI target group.

\section{Conclusions}

Based on the results of the study it can be concluded that the provision of the GBID facility in Indonesia's manufacturing industries significantly increases the growth and competitiveness of Indonesia's manufacturing industry. The increase in growth mainly occurs in the production growth indicator where of the 110 companies receiving GBID facility surveyed, $62.73 \%$ of the companies experienced an increase in production volume and $69 \%$ experienced an increase in the volume of raw materials. The increase in company competitiveness mainly occurs in the indicators of the competitiveness of production costs, sales growth, profits, and company productivity. Of the 110 companies surveyed, $88 \%$ experienced a decrease in production costs, 59\% experienced an increase in the competitiveness of production costs, $72.7 \%$ experienced a growth in sales, $60 \%$ experienced an increase in company productivity, and $77.27 \%$ experienced an increase in profits. Other growth and competitiveness indicators increased which varies from around $20 \%$ to $50 \%$.

In this study, of the 110 manufacturing industries surveyed, 56\% were under the guidance of CTMI, $43 \%$ were under the guidance of MMTEI, and 1\% under the guidance of the Directorate General of Agro-Industries. The provision of the GBID facility had different effects on companies under different target sectors. More companies under MMTEI have experienced in innovation increasing, time-to-market competitiveness, and machine modernization after being given GBID facility, while more companies under CTMI have experienced in production growth, increasing in competitiveness in production costs, quality, delivery time, sales growth, productivity, human capital, absorption of production labor, and tax payments. The difference is due to differences like production, product standardization, product cycle times, and technological intensity. The results also show that differences in the frequency of GBID facility only affected increasing the price competitiveness of the company's products.

The research also shows that the frequency of companies in obtaining the GBID facility would also affect the increase in the price competitiveness of the company's products. However, the effect of the GBID facility on other indicators, in addition to price competition, has not been seen in this study. Related to the nature of production, GBID facility is better suited to companies that have production plans than companies that are project or job orders because the results are more optimal. 


\section{Acknowledgment}

This research was supported and funded by PT. Surveyor Indonesia to complete the Industry Verification Report material in the framework of the 2018 Fiscal Year Government Borne Import Duty. We are grateful to our colleague, Mr. Firza Mahdar, head of the PIK business unit. PT. Indonesian Surveyor, Mr. M. Yusuf Hermawan, as Project Manager for the Government Borne Import Duty Project, Mr. Anggoro as Surveyor Coordinator, and all Surveyors PT. Surveyor Indonesia who assist in the research data collection process.

\section{Appendix A. Questionnaire Items}

\begin{tabular}{|c|c|c|c|}
\hline Indicators & Sub Indicators & Item questions & Sources \\
\hline \multirow[t]{2}{*}{$\begin{array}{l}\text { Production } \\
\text { growth }\end{array}$} & Production volume & $\begin{array}{l}\text { What is the production volume after the company receives the GBID } \\
\text { facility? }\end{array}$ & \multirow[t]{2}{*}[14]{} \\
\hline & Raw material & $\begin{array}{l}\text { What is the volume of raw materials purchased after the company } \\
\text { receives the GBID facility? }\end{array}$ & \\
\hline \multirow[t]{2}{*}{$\begin{array}{l}\text { Cost } \\
\text { competitiveness }\end{array}$} & Production cost & $\begin{array}{l}\text { What are the production costs after the company receives the GBID } \\
\text { facility? }\end{array}$ & \multirow[t]{2}{*}[8]{,$[11]$} \\
\hline & $\begin{array}{l}\text { Competitiveness of } \\
\text { production cost }\end{array}$ & $\begin{array}{l}\text { How is the competitiveness of production costs after the company } \\
\text { receives the GBID facility? }\end{array}$ & \\
\hline \multirow[t]{2}{*}{$\begin{array}{l}\text { Price } \\
\text { competitiveness }\end{array}$} & $\begin{array}{l}\text { the selling price of the } \\
\text { product }\end{array}$ & $\begin{array}{l}\text { What is the selling price of the product after the company has received } \\
\text { the GBID facility? }\end{array}$ & \multirow[t]{2}{*}{ [9], [11] } \\
\hline & $\begin{array}{l}\text { the competitiveness of the } \\
\text { product selling price al }\end{array}$ & $\begin{array}{l}\text { What is the competitiveness of the product selling price after the } \\
\text { company receives the GBID facility? }\end{array}$ & \\
\hline \multirow[t]{2}{*}{$\begin{array}{l}\text { Quality } \\
\text { competitiveness }\end{array}$} & the quality of the product & $\begin{array}{l}\text { What is the quality of the product after the company receives the GBID } \\
\text { facility? }\end{array}$ & \multirow[t]{2}{*}[8]{$,[9],[12]$} \\
\hline & $\begin{array}{l}\text { the competitiveness of } \\
\text { product quality }\end{array}$ & $\begin{array}{l}\text { What is the competitiveness of product quality after the company } \\
\text { receives the GBID facility? }\end{array}$ & \\
\hline \multirow[t]{3}{*}{ Delivery time } & Accuracy of delivery time & $\begin{array}{l}\text { How accurate is the product delivery time after the company receives } \\
\text { the GBID facility? }\end{array}$ & \multirow[t]{3}{*}[8]{,$[9]$} \\
\hline & $\begin{array}{l}\text { The speed of delivery time } \\
\text { product }\end{array}$ & $\begin{array}{l}\text { What is the speed of product delivery time after the company receives } \\
\text { the GBID facility? }\end{array}$ & \\
\hline & $\begin{array}{l}\text { delivery time } \\
\text { competitiveness }\end{array}$ & $\begin{array}{l}\text { How competitive is the product delivery time after the company } \\
\text { receives the GBID facility? }\end{array}$ & \\
\hline Innovation & $\begin{array}{l}\text { the number of product } \\
\text { innovations }\end{array}$ & $\begin{array}{l}\text { What is the number of product innovations after the company receives } \\
\text { the GBID facility? }\end{array}$ & {$[8],[9],[11],[12]$} \\
\hline Time to market & $\begin{array}{l}\text { the speed of product } \\
\text { launching }\end{array}$ & $\begin{array}{l}\text { What is the speed of product launching after the company has received } \\
\text { GBID facility }\end{array}$ & [9] \\
\hline \multirow[t]{3}{*}{ Market share } & $\begin{array}{l}\text { the market share in the local } \\
\text { market }\end{array}$ & $\begin{array}{l}\text { What is the market share in the local market after the company receives } \\
\text { the GBID facility? }\end{array}$ & \multirow[t]{3}{*}{ [10], [11], [13] } \\
\hline & $\begin{array}{l}\text { the market share in foreign } \\
\text { markets }\end{array}$ & $\begin{array}{l}\text { What is the market share in foreign markets after the company receives } \\
\text { the GBID facility? }\end{array}$ & \\
\hline & the growth in product sales & $\begin{array}{l}\text { What is the growth in product sales after the company receives the } \\
\text { GBID facility? }\end{array}$ & \\
\hline $\begin{array}{l}\text { Company } \\
\text { productivity }\end{array}$ & the company's productivity & $\begin{array}{l}\text { What is the company's productivity after the company receives the } \\
\text { GBID facility? }\end{array}$ & {$[10],[11]$} \\
\hline $\begin{array}{l}\text { The } \\
\text { profitability of } \\
\text { the company }\end{array}$ & the company's profitability & $\begin{array}{l}\text { What is the company's profitability after the company receives the } \\
\text { GBID facility? }\end{array}$ & [10], [11], [13] \\
\hline \multirow[t]{2}{*}{$\begin{array}{l}\text { Modernization } \\
\text { of machines }\end{array}$} & the investment in machinery & $\begin{array}{l}\text { What is the investment in machinery after the company receives the } \\
\text { GBID facility? }\end{array}$ & \multirow[t]{2}{*}[12]{} \\
\hline & the quality of the technology & $\begin{array}{l}\text { What is the quality of the technology used after the company has } \\
\text { received the GBID facility? }\end{array}$ & \\
\hline \multirow[t]{2}{*}{ Human capital } & $\begin{array}{l}\text { the competencies of the } \\
\text { production workforce }\end{array}$ & $\begin{array}{l}\text { What are the competencies of the production workforce after the } \\
\text { company has received the GBID facility? }\end{array}$ & \multirow[t]{2}{*}[12]{} \\
\hline & $\begin{array}{l}\text { the productivity of the } \\
\text { production workforce }\end{array}$ & $\begin{array}{l}\text { What is the productivity of the production workforce after the company } \\
\text { receives the GBID facility? }\end{array}$ & \\
\hline \multirow[t]{2}{*}{$\begin{array}{l}\text { Labors } \\
\text { absorption }\end{array}$} & $\begin{array}{l}\text { the number of production } \\
\text { workers }\end{array}$ & $\begin{array}{l}\text { What is the number of production workers after the company receives } \\
\text { the GBID facility? }\end{array}$ & \multirow[t]{4}{*}{ [16] } \\
\hline & $\begin{array}{l}\text { the number of non-production } \\
\text { workers }\end{array}$ & $\begin{array}{l}\text { What is the number of non-production workers after the company } \\
\text { receives the GBID facility? }\end{array}$ & \\
\hline \multirow{2}{*}{$\begin{array}{l}\text { Contribute to } \\
\text { increasing state } \\
\text { revenues }\end{array}$} & the corporate tax & $\begin{array}{l}\text { What is the corporate tax after the company receives the GBID } \\
\text { facility? }\end{array}$ & \\
\hline & $\begin{array}{l}\text { labor tax paid by the } \\
\text { company }\end{array}$ & $\begin{array}{l}\text { What is the labor tax that the company pays after the company receives } \\
\text { the GBID facility? }\end{array}$ & \\
\hline
\end{tabular}




\section{References}

[1] Silalahi, T., \& Chawwa, T. (2012). Relative Effectiveness Of Indonesian Policy Choices During Financial Crisis. Buletin Ekonomi Moneter Dan Perbankan, 14(2), 177-219.

[2] Putra, H. P. H. (2013). Analisis Dampak Pemanfaatan Kebijakan Bea Masuk Ditanggung Pemerintah (BMDTP) Terhadap Produktivitas Sektor Industri Tertentu. Jurnal Ekonomi Dan Pembangunan, 23(2), 113-123.

[3] Amiti, M., \& Konings, J. (2007). Trade Liberalization, Intermediate Inputs, And Productivity: Evidence From Indonesia. The American Economic Review, 97(5), 1611-1638.

[4] Kementerian Keuangan Republik Indonesia. Peraturan Menteri Keuangan Republik Indonesia No. 248/PMK.011/2014 Tentang Bea Masuk Ditanggung Pemerintah Atas Impor Barang Dan Bahan Untuk Memproduksi Barang Dan/Atau Jasa Guna Kepentingan Umum Dan Peningkatan Daya Saing Industri Sektor Tertentu.

[5] Kementerian Perindustrian Republik Indonesia. (2019). Laporan Hasil Verifikasi Industri Perusahaan Penerima Fasilitas BMDP 2008-2018.

[6] Samosir, A. (2012). Analisis Pemberian Bea Masuk Ditanggung Pemerintah (BMDTP) Tahun 2010. Kajian Ekonomi Dan Keuangan, 16(23), 111-132.

[7] Sachitra, V. (2016). Review Of Competitive Advantage Measurements: Reference On Agribusiness Sector. Journal Of Scientific Research And Report, 12(6), 1-11.

[8] Muhardi. (2007). Strategi Operasi Untuk Keunggulan Bersaing. Jakarta: Ghalia Indonesia.

[9] Thatte, A. A. (2007). Competitive Advantage Of A Firm Through Supply Chain Responsiveness And SCM Practices. Doctoral Dissertation, The University Of Toledo. Available :Http://202.154.59.182/Ejournal/Fil Es/Thatte_A_-_Competitive_Advanta.Pdf

[10] Depperu, D., \& Cerrato, D. (2005). Analyzing International Competitiveness At The Firm Level : Concepts And Measures. Quaderni Del Dipartimento Di Scienze Economiche E Sociali, 32, 2007-2013.

[11] Buckley, P. J., Pass, C. L., \& Prescott, K. (1988). Measures Of International Competitiveness: A Critical Survey. Journal Of Marketing Management, 4(2), 175-200.

[12] Johnson, G., Whittington, R., Regner, P., Scholes, K., \& Angwin D. (2017). Exploring Corporate Strategy: Text And Cases, $11^{\text {th }}$ Edition. Essex: Pearson Education Limited.

[13] Notta, O., Vlachvei, A., \& Samathrakis, V. (2010). Competitiveness - The Case Of Greek Food Manufacturing Firms. International Journal Of Arts And Sciences, 3(7), 211-225.

[14] Bagshaw, K. B. (2015). Assessing The Capacity Strategic Options On Capacity Utilisation Of Manufacturing Firms In Rivers State, Nigeria. International Journal Of Business And Social Science, 6(10), 64-75.

[15] Harahap, M., Sinaga, B., Manurung, A. H., \& Maulana, T. N. A. (2018). Impact Of Policies And Macroeconomic Variables On Tax Revenue And Effective Tax Rate Of Infrastructure, Utility, And Transportation Sector Companies Listed In Indonesia Stock Exchange. International Journal of Economics And Financial Issues, 8(3), 95-104.

[16] Astuti, T.P., \& Aryani, Y. A. (2016). Tren Penghindaran Pajak Perusahaan Manufaktur Di Indonesia Yang Terdaftar Di BEI Tahun 2001-2014. Jurnal Akuntansi, 20(03), 375-388.

[17] Nwaeke, L. I., \& Onyebuchi, O. (2017). Impact of Manpower Training and Development on Organizational Productivity And Performance A Theoretical Review. European Journal Of Business And Management, 9(4), 153-159.

[18] Koroglu, B. A., \& Eceral, T. O. (2015). Human Capital And Innovation Capacity Of Firms In Defense And Aviation Industry In Ankara. Procedia: Social And Behavioral Sciences, 195, 1583-1592.

[19] Forrester, S. V., Ustinova, G. H., Kosyakova, I. V., Ronhina, N. V., \& Suraeva, M. O. (2016). Human Capital In The Innovative Conditions, IEJME - Mathematics Education, 11(8), 3048-3065.

[20] Ibraimi, S., Bexheti, A., Zuferi, G., Rexhepi, G., \& Ramadani, V. (2016). Enhancing Flexible Manufacturing Competence. The Eurasia Proceedings Of Educational \& Social Sciences (EPESS), 5, 378-384.

[21] Prihadyanti, D. (2015). Pembelajaran Teknologi Di Perusahaan Manufaktur Berintensitas Teknologi Tinggi Dan Menengah-Tinggi. Jurnal Manajemen Teknologi, 14(10), 1-14.

[22] Solomon, R., Sandborn, P., \& Pecth, M. (2000). Electronic Part Life Cycle Concepts And Obsolescence Forecasting. IEEE Transactions On Components And Packaging Technologies, 23(4), 707-717.

[23] Synnes, E. L., \& Welo, T. (2016). Bridging The Gap Between High And Low-Volume Production Through Enhancement Of Integrative Capabilities. Elsevier, 5, 26-40.

[24] Augustina Asih Rumanti Vania Hadisurya (2017). Analysis Of Innovation Based On Technometric Model To Predicttechnology Life Cycle In Indonesian SME, International Journal of Innovation in Enterprise System, Volume 01, Issue 01, 29-36

[25] Zawislak, P. A., Fracasso, E. M., \& Gamarra, J. T. (2018). Technological Intensity and Innovation Capability in Industrial Firms. Innovation \& Management Review. 15(2), 189-207. 